\title{
Dimensions of Complexity in Community Participation through ICT Design
}

\author{
Karen George \\ School of Computer, Engineering \\ and Information Science \\ Dr. Petia Sice \\ School of Computer, Engineering \\ and Information Science \\ Northumbria University in Newcastle Northumbria University in Newcastle \\ karen.george@northumbria.ac.uk \\ petia.sice@northumbria.ac.uk \\ Prof. Robert Young \\ School of Design \\ Northumbria University in Newcastle \\ Newcastle upon Tyne \\ DERY1@central.unn.ac.uk
}

\author{
Dr. Jeremy Ellman \\ School of Computer, Engineering \\ and Information Science \\ Northumbria University in Newcastle \\ jeremy.ellman@northumbria.ac.uk
}

\author{
Prof. Safwat Mansi \\ School of Computer, Engineering \\ and Information Science \\ Northumbria University in Newcastle \\ safwat.mansi@northumbria.ac.uk
}

\begin{abstract}
The aim of this research is to develop a frame of reference for effective community participation through ICT design, applying both complexity and design perspectives to recognise the role of local interactions. This links to both the current UK 'Empowering Local Communities' policy agenda and to practical ways of developing community participation; in keeping with the aspirations of the Big Society (Cabinet Office, 2011).
\end{abstract}

Key Words - Community Participation, Information Communication Technology \& Management, Complexity Theory, Big Society, Design Theory and the Third Sector.

\section{Introduction}

The researcher worked and volunteered in the Third Sector for thirty years. She completed her MSc research in Strategic Information and Knowledge Management in the Community Sector utilising McElroy's (2003) theory, the Complex Adaptive System, an e-adoption ladder and developed an adaptive solution which the researcher is presently setting up as a business.

\subsection{Background}

The researcher is reviewing literature and awaiting feedback on her Initial Project Application for her doctorate, which aims to develop a frame of reference for the use of ICT for effective community participation applying both complexity and design perspectives to recognise the role of local interactions.

This is linked to both the current UK 'Empowering Local Communities' policy agenda and to practical ways of developing engagement capacity, in keeping with the aspirations of the 'Big Society' (Cabinet Office, 2011; Communities and Local
Government, 2008a, 2008b and 2009). It is important to focus on understanding the quality of interactions within community participation. What are the critical tipping points that motivate people to participate and how can these be used to design improved information communication?

Primary Objectives are to work with sections of the government, Third Sector, Community Organisations and the general public to:

(i) Evaluate the challenges and needs of communication and information management in Community Participation.

(ii) Develop a model for meaningful and beneficial engagement through use of ICT for effective Community Participation (Niu, M. et al, 2008; Sice, P. \& French, I., 2006 and Small, A., Sice, P. \& Venus, T., 2008).

The research will more specifically look into the following areas of knowledge:

- Deliverables;

- Customer Experience \& Benefits; 
Community Participation Characterised For Information Communication Technology

Karen George, Dr Petia Sice, Prof. Robert Young, Dr Jeremy Ellman, Prof Safwat Mansi

- Happiness, Wellbeing,

Sustainability \& Empowerment;

- Governance;

- Politics \& Policies;

- Resources;

- Communication Modalities \& Platforms;

- Disciplines;

- Systems Thinking, Operational \& Organisational Management;

- Design Ethnography - Diversity of People \& Social Barriers;

- Computer Science - Information \& Communication Management;

- Complexity Science;

- Human Centred Design;

- $\mathrm{HCl}$;

- Activities;

- Collaborative Practices;

- Accountability \& Measures of Success;

- Conceptual Frameworks \& Theories;

- Social Innovation;

The research is being initiated by looking at narratives of experiences from the researchers past work which will be told to the research team for further questioning and evaluating. The research will then move to other qualitative data collection.

\subsection{PROPOSAL}

The project depicts an exploratory study aiming to investigate the complex characteristics of tipping points for Community Participation stakeholders through exploring the applicability of information management and ICT to support collaborative practices and multi-criteria decision making to enable positive experiences (Communities and Local Government, 2008; Communities and Local Government, 2008a, 2008b and 2009). Building on the researcher's master's part of the doctorate research involves evaluating a collaborative international study focused on Community Participation for employment and training of socially isolated people; immigrants, homeless, third generation unemployed and long term carers. The main part of the research will be focused in Tyne and Wear within the 'Big Society' context focusing purely on Community Participation with Third Sector partners and the local community. The research will involve sense making via interviews and workshops (Cabinet Office, 2011).

The initial research will be that of a narrative investigation following complexity theorists such as Stacey (2010) and Mowles et al, 2008 \& Mowles, 2010) (Hirschfeld, R. \& Lämmel, R. 2005).

\section{REFERENCES}

Cabinet Office (2011) Big Society - overview: http://www.cabinetoffice.gov.uk/content/big-societyoverview (Retrieved: 28/03/11).

Charities Commission (2004) RS8 - Transparency and Accountability. shttp://www.charitycommission.gov.uk/Publications/rs8.aspx\%20>

(Retrieved: 30/01/11).

Communities and Local Government. (2008a)

Communities in control: real people, real power. http://www.communities.gov.uk/documents/commu nities/pdf/886045.pdf (Retrieved: 10/01/11)

Communities and Local Government. (2008b) Empowering communities to influence local decision making.

http://www.communities.gov.uk/documents/localgo vernment/pdf/1241999 (Retrieved: 10/01/11)

Communities and Local Government. (2009) Empowering communities to influence local decision making. http://www.communities.gov.uk/documents/localgo vernment/pdf/1241999 (Retrieved: 10/01/11).

Hirschfeld, R. \& Lämmel, R. (2005) 'Reflective Designs -- An Overview', Electronic Notes in Theoretical Computer Science, 127 (3), pp. 55-58.

McElroy, M. W. (2003) The new knowledge management: complexity, learning, \& sustainable innovation. Butterworth-Heinemann, London.

Mowles, C., Stacey, R. \& Griffin, D. (2008) 'What contribution can insights from the complexity sciences make to the theory and practice of development management?', Journal of International Development, 20 (6), pp. 804-820.

Mowles, C. (2010) 'Post-foundational development management-power, politics and complexity', Public Administration and Development, 30 (2), pp. 149-158.

Niu, M. et al (2008) 'Exploring the behaviour of a centralised supply chain at Draeger Safety UK', International Journal of Information Systems and Supply Chain Management,

Sice, P. \& French, I. (2006) 'A holistic frame-ofreference for modelling social systems', Kybernetes, 35 (6), pp. 851 - 864.

Small, A., Sice, P. \& Venus, T. (2008) 'A framework for promoting learning in IS design and implementation', Learning organization http://hdl.handle.net/10145/77383 (Retrieved: 13/01/11).

Stacey, R. D. (2010) Complexity and organizational reality: uncertainty and the need to rethink management after the collapse of investment capitalism. Routledge, London.

University of Siegen (2010) Study on the Social Impact of ICT. http://ec.europa.eu/information society/eeurope/i20 10/docs/eda/social impact of ict exec sum.pdf (Retrieved: 13/03/11). 